\title{
IN DE SPOTLIGHT
}

\section{De wetenschap achter digitaal welzijn en disconnectie} Op zoek naar een gezonde balans tussen schermtijd en disconnectie

Mariek Vanden Abeele

Universiteit Gent

mariek.vandenabeele@ugent.be

Digitale media zoals smartphones en laptops laten ons toe om altijd en overal verbonden te zijn. Die voortdurende verbondenheid leidt tot een interessante nieuwe paradox in ons leven: we halen weliswaar veel voordelen uit het altijd en overal toegang hebben tot informatie, onze sociale netwerken en allerhande diensten, maar die voordelen gaan gepaard met allerhande nadelen, zoals het voortdurend afgeleid zijn door technologie, de stress die ervaren wordt door 'altijd aan' te staan, en moeheid en mentale overbelasting na een lange dag vol schermtijd. De covid-19-pandemie heeft deze paradox op scherp gesteld. Niet alleen de voordelen, maar ook de nadelen van digitale verbondenheid werden gevoelig zichtbaarder.

\section{Digitaal welzijn}

In de wetenschap is een nieuw begrip op de voorgrond getreden dat uitdrukking geeft aan deze paradoxale ervaring, namelijk 'digitaal welzijn'. Digitaal welzijn verwijst naar hoe individuen de balans tussen de voor- en nadelen van digitale verbondenheid ervaren. Die balans is optimaal wanneer het gebruik van digitale media ons maximaal plezier verschaft en ondersteuning biedt bij de organisatie van ons dagelijks leven, terwijl we zo weinig mogelijk controleverlies, conflict of negatieve emoties ervaren.

Een optimale staat van digitaal welzijn bereiken is echter geen gemakkelijke klus. Veel mensen zijn ontevreden over de tijd die ze doorbrengen op digitale schermen, maar vinden het moeilijk om daar verandering in te brengen. Dat komt omdat de digitale balans van iedere persoon het resultaat vormt van een complexe interactie tussen individuele, technologische en contextuele factoren. 
Wat individuele factoren betreft, toont onderzoek dat sommige persoonlijkheidskenmerken vatbaarder maken om een problematische relatie met technologie te ontwikkelen. Zo verliezen personen die erg impulsief zijn gemakkelijker de controle over hun gebruik, en kunnen we verwachten dat mensen met een hogere fear of missing out waakzamer zijn voor inkomende notificaties, waardoor ze mogelijk vaker hun werk- of sociale activiteiten verstoren door hun smartphone te checken.

Ook technologische factoren spelen een rol. Digitale technologieën zoals smartphones, laptops en tablets geven toegang tot talloze applicaties en toepassingen die deel uitmaken van de hedendaagse aandachtseconomie: we betalen geen rechtstreekse monetaire vergoeding voor hun gebruik, maar vergoeden de makers onrechtstreeks, door toegang te geven tot onze data. Deze data, die verrijkt kunnen worden met andere datastromen en allerhande meta-data, zijn waardevol voor onder andere adverteerders, die zo hun marketingcommunicatie kunnen optimaliseren door verregaande personalisatie. Maar omdat onze data zo waardevol zijn, worden bij het ontwerp van digitale platformen vaak ontwerpprincipes gehanteerd die ons aanzetten om vaker, langer en met meer aandacht tijd door te brengen op het platform. Sommige van de features, zoals notificatiesystemen, kunnen ons checkgedrag mee sturen. Bijgevolg kunnen technologische ingrepen, zoals het in- of uitschakelen van deze notificaties, mogelijks al een rol spelen in het beïnvloeden van ons digitaal welzijn.

Naast individuele en technologische factoren moeten we ook rekening houden met de context. Daarbij kunnen we onderscheid maken tussen de situationele en de sociale of institutionele context. Wat de situationele context betreft, kan de telefoon in sommige situaties zorgen voor een ongewenste verstoring, ofwel een 'technoferentie' van onze primaire activiteiten. Dit is in het bijzonder problematisch wanneer er een doelconflict bestaat tussen wat je wil doen - voetbal kijken op tv - en wat je moet doen - studeren voor een belangrijk tentamen. Dit soort conflict kan ervoor zorgen dat je het studeren begint uit te stellen door op je telefoon te kijken, of dat je tijdens het studeren je telefoon vaker checkt, mogelijks tot je eigen frustratie, waardoor schaamte- en schuldgevoelens kunnen ontstaan. Je telefoongebruik kan ook je sociale interacties verstoren, wat op zijn beurt kan leiden tot verminderde relatiekwaliteit en zelfs conflict binnen je relaties.

Deze situationele context staat niet los van de sociale en institutionele omgeving waarin mensen leven. Binnen partnerrelaties, sociale groepen 
zoals gezinnen of vriendengroepen, en instituties zoals werkorganisaties of scholen kunnen formele en informele regels, normen en verwachtingen bestaan ten aanzien van ieders beschikbaarheid en omgang met digitale media. Soms kunnen die regels, normen en verwachtingen leiden tot rolconflicten, bijvoorbeeld wanneer je kwaliteitsvolle tijd wil doorbrengen met je gezin, maar steeds berichten ontvangt van je werkgever met een urgente vraag om een werktaak op te nemen.

Het samenspel van individuele, technologische en contextuele factoren maakt dat digitaal welzijn een complex en dynamisch gegeven is. Desondanks zien we dat mensen pogingen doen om hun digitale balans te verbeteren.

\section{Disconnectie}

Mensen ondernemen actie om een betere balans te vinden tussen de voor-en nadelen van digitale verbondenheid. Dat doen ze veelal door aan 'disconnectie' te doen. Disconnectie gebeurt wanneer er op korte of langere termijn limieten worden gesteld aan digitale verbondenheid, veelal met het doel om gezondheid, productiviteit en welzijn te vergroten. Disconnectie kan vele vormen aannemen. We zien disconnectie bijvoorbeeld op het niveau van het individu, de groep en het instituut. Individuele disconnectie verwijst naar het opleggen van regels en limieten aan jezelf, bijvoorbeeld door de smartphone weg te leggen tijdens werktaken. Op groepsniveau kunnen formele afspraken gemaakt worden, bijvoorbeeld over smartphonegebruik aan de eettafel. Ook overheden en organisaties kunnen disconnectie reguleren en faciliteren - denk bijvoorbeeld aan de Franse arbeidswetgeving, waarin le droix à la déconnexion, ofwel het recht op disconnectie, expliciet opgenomen is.

De zoektocht naar digitaal welzijn is opgepikt door de industrie. Er bestaat intussen een rijk palet aan producten en diensten die bedoeld zijn om mensen te helpen bij het disconnecteren. Zo kan je op digital-detox-vakantie, bestaat er allerhande zelfhulpliteratuur en coaching om tot een betere digitale balans te komen, kan je producten kopen om je digitale media op te sluiten of fysiek te vergrendelen, en is er een rijk aanbod aan (mobiele) applicaties waarmee mensen limieten kunnen stellen aan hun schermtijd. Deze applicaties zijn niet onomstreden. Ten eerste zijn sommige ontwikkeld door dezelfde technologiereuzen die platformen uitbaten met een 
'verslavend' design. De technologiereuzen nemen hierdoor een duale rol in, als aanbieders van zowel het probleem als de oplossing.

Ten tweede roept de groei in initiatieven omtrent disconnectie fundamentele vragen op over onze samenleving. Disconnectie wordt bijvoorbeeld vaak gezien als een strategie om tijdelijk te kunnen onthaasten, maar lijkt eerder de symptomen van het jachtige leven te bestrijden dan werkelijk sociale verandering te brengen. In communicatie over disconnectie wordt bijvoorbeeld soms verwezen naar disconnectie als manier om nóg productiever te kunnen zijn. Ook brengt disconnectie nieuwe vraagstukken met zich mee omtrent macht en ongelijkheid. Zo kunnen we ons de vraag stellen of disconnectie een privilege is, en of disconnectie altijd vrijwillig gebeurt. Zeker in groeps- of institutionele contexten kunnen er machtsverhoudingen meespelen, en kan disconnectie mogelijks zelf een nieuw doelwit van surveillance worden waaraan straffen en beloningen verbonden worden.

\section{Implicaties voor praktijk en maatschappij}

Veel vragen over digitaal welzijn en disconnectie blijven voorlopig onbeantwoord. Ze zullen de inzet worden van heel wat academisch en toegepast onderzoek in het komende decennium. Zo zullen vragen over de effectiviteit, alsook de mogelijk onbedoelde neveneffecten van digitalewelzijnsinterventies ongetwijfeld centraal staan.

Toch kunnen we alvast enkele voorzichtige conclusies trekken. Zo weten we dat er geen one-size-fits-all-oplossing bestaat: digitaalmediagebruik en de effecten ervan uiten zich op specifieke manieren bij specifieke individuen, die zich in specifieke omstandigheden kunnen bevinden. Deze vaststelling heeft belangrijke implicaties voor de praktijk. Of het nu in de gezins-, de school- of de werkcontext is, bij problematieken met betrekking tot digitaal welzijn kan het best een analyse gemaakt worden van de verscheidene individuele, technologische en contextuele factoren die een rol spelen in de problematiek, om zoveel mogelijk tot een persoons- en mogelijks situatiespecifieke aanpak te komen. Verder onderzoek naar disconnectie kan hopelijk in de toekomst hulp bieden, door beter te informeren over welke vormen van disconnectie het meest kans van slagen hebben, rekening houdend met genoemde factoren. 
Het is maatschappelijk belangrijk dat we hierbij vermijden om digitaal welzijn te reduceren tot een louter individuele verantwoordelijkheid. Immers, ook de industrie, die werkt volgens de principes van de aandachtseconomie, en de context, die leidt tot situaties waarin individuen mogelijks onverzoenbare conflicten ervaren, spelen een rol. Dit betekent dat we ook digitale media niet per definitie als zondebok mogen aanduiden. In problematieken zoals burn-out, bijvoorbeeld, wordt vaak naar digitale verbondenheid verwezen als een cruciale oorzaak, maar negatieve ervaringen in relatie tot deze digitale verbondenheid kunnen we niet los zien van de normen of (waargenomen) verwachtingen om 'altijd aan te staan' die mensen mogelijks ervaren in hun sociale en institutionele context.

Tot slot is het zinvol om kritisch te kijken naar digitalewelzijnsinterventies en wat we als samenleving van deze interventies verwachten en verlangen. Het menselijk verlangen naar disconnectie lijkt te signaleren dat mensen fundamentele problemen ervaren met de 'ratrace' van het leven in onze hedendaagse samenleving. Is disconnectie dan een gepaste en duurzame vorm van onthaasting, of eerder een schijnoplossing die het snelle levensritme uiteindelijk in stand houdt? Bovendien kan disconnectie zowel bestaande als nieuwe machtsdynamieken en ongelijkheden in de samenleving bestendigen. Het lijkt dan ook aangewezen om interventies kritisch tegen het licht te houden. Hopelijk kan wetenschappelijk onderzoek een bijdrage leveren aan het digitaal welzijn van de burger door antwoord te bieden op deze vragen.

\section{Literatuur}

Vanden Abeele, M. M. P. (2020). Digital wellbeing as a dynamic construct. Communication Theory, qtaa024. https://doi.org/10.1093/ct/qtaa024 